\title{
Комунікативна раціональність як феноменологічна складова правової ідентифікації
}

\author{
Кравцов Ю.С., Дніпровський державний технічний університет
}

Зміни, що відбуваються в сучасному світі, сучасна соціокультурна ситуація, вимагають від сучасної людини мобільності і адекватної відповіді на сучасні вимоги суспільства, ставлять ії перед необхідністю перегляду традиційних цілей і орієнтирів. В статті автор показує, що у педагогічному плані це означає, що основним результатом освіти повинна стати не система знань, умінь і навичок сама по собі, а набір сучасних ключових компетенцій в інтелектуальній, соціально-правовій, комунікативній, інформаційній сферах. Автор виходить 3 того, що на зміну старій парадигмі сьогодні приходить парадигма інтерсуб'єктивного розуміння і комунікації. Фокус сьогоднішніх досліджень перемістився від когнітивно-інструментальної до комунікативної раціональності. Автор зазначає, що особливістю сучасного соціального пізнання, яка задає нову парадигму, $є$ те, що воно здійснюється через аналіз того, якими уявленнями опосередковано саме пізнавальне ставлення до соціальних феноменів, що супроводжується глибоким переосмисленням комунікативної природи соціальної реальності, змін у соціально-комунікативній сфері.

Ключові слова: комунікативна раціональність; модернізація освіти; соціальне пізнання; парадигма інтерсуб'єктивного розуміння; комунікативна реальність; феноменологічна орієнтація; розуміння «Іншого»

\section{Communicative rationality as a phenomenological component of legal identification}

\section{Kravtsov Y.S., Dniprovsky State Technical University}

The changes taking place in the modern world, the modern socio-cultural situation, require modern human mobility and an adequate response to the modern demands of society, put it before the need to revise traditional goals and landmarks. The article deals with the new situation in the education sector, which is given the peculiarities of modern stage of development of the education system and by the need to rethink the principles of values education in the XXI century. through the prism of sustainable development priorities . Feature of modern social cognition that sets a new paradigm is that it is carried out through the analysis of what representations mediated self cognitive attitude to social phenomena, accompanied by deep rekonstruction communicative nature of social reality, changes in the socio - communicative sphere. In the article the author shows that in the pedagogical plan it means that the main result of education should not be a system of knowledge, skills and skills by itself, but a set of modern key competencies in the intellectual, social, legal, communicative, informational spheres. The author proceeds from the fact that replacing the old paradigm today comes the paradigm of intersubjective understanding and communication. The focus of today's research has shifted from cognitive-instrumental to communicative rationality. The author notes that the peculiarity of modern social knowledge, which sets the new paradigm, is that it is carried out through an analysis of what representations are mediated by the cognitive attitude to social phenomena, which is accompanied by a profound reassessment of the communicative nature of social reality, changes in social communicative the field.

Keywords: communicative rationality; modernization of education; social cognition; paradigm of intersubjective understanding; communicative reality; phenomenological orientation; understanding of the «Other»

\section{Коммуникативная рациональность как феноменологическая составляющая правовой идентификации}

\section{Кравцов Ю.С., Днепровский государственный технический университет}

Изменения, происходящие в современном мире, современная социокультурная ситуация требуют от современного человека мобильности и адекватного ответа на современные требования общества, ставят его перед необходимостью пересмотра традиционных целей и ориентиров. В статье автор показывает, что в педагогическом плане это означает, что основным результатом образования должна стать не система знаний, умений и навыков сама по себе, а набор современных ключевых компетенций в интеллектуальной, социально-правовой, коммуникативной, информационной сферах. Автор исходит из того, что на смену старой парадигме сегодня приходит парадигма интерсубъективного понимания и коммуникации. Фокус сегодняшних исследований переместился от когнитивно-инструментальной к коммуникативной рациональности. Автор отмечает, что особенностью современного социального познания, задающей новую парадигму, является то, что оно осуществляется через анализ того, какими представлениями опосредовано же познавательное 
отношение к социальным феноменам, что сопровождается глубоким переосмыслением коммуникативной природы социальной реальности, изменений в социально-коммуникативной сфере.

Ключевые слова: коммуникативная рациональность; модернизация образования; социальное познание; парадигма интерсубъективного понимания; коммуникативная реальность; феноменологическая ориентация; понимание «Другого»

\section{Постановка проблеми.}

$\Pi$ ошук індивідом, групою, суспі-лльством ідентичності, яка задовольняє потребу в безпеці і захисті, потребу прина ᄀлежності до певної групи чи спільноти, потребу особистості бути визнаною інши $\urcorner м и ~ \epsilon$ сьогодні найактуальнішою. Дослідження іде $\urcorner \mathrm{H}-$ тичності стає сьогодні незалежною галуззю знання, вона стає призмою, через яку розглядаються, оцінюються і вивчаються більшість важливих рис сучасного жит $\neg$ тя. В кінці XX ст. теза про цінність людської індивідуальності доповнилась тверᄀдженням про важливість визнання тієї чи іншої ідентичності суспільством.

На всьому «постсоціалістичному» просторі проблема правової ідентичності була поставлена основним завданням при конструюванні «нових» ідеологій. Тим часом сьогодні у всіх державах, що національно самовизначаються як орієнтири самоідентифікації особи, висуваються і пропагуються критерії, що відіграють роль зовнішніх (не сутнісних) атрибутів: територія, офіційна мова, демонстрація в зовнішніх рисах елементів національної культури, котрі мають емблематичний характер. При цьому пошук метафізичного, духовного коріння, відновлення і збереження традиційної спадкоємності у прихильників реідеологзації не викликає інтересу. Звернення до традиції легко замінюється штучно культивованими міфами, але про дійсно наукове обгрунтовування національних інтересів практично не йдеться. При цьому політики цілком задовольняються запропонованими гаслами, які оцінюються з точки зору ефективності маніпулювання громадською думкою [7, с.55].

\section{Аналіз досліджень і публікаці.}

Формування особистісної культури людини XXI століття включає в якості найважливішого компонента комунікативну компетентність. Не випадково увага дослідників все частіше звертається до проблем комунікації (А. А. Бондалев, А. А. Леонтьев, М. К. Мамардашвили иі ін.). Дослідженню комунікації як соціокультурного феномена присвячені роботи І. П. Андрущенко, Э. Н. Гусинского и Ю. М. Турчаниновой, І. А. Зязюна, Г. Л. Ильина, Л. А. Микешиной, Ю. А. Огородникова, А. П. Огурцова, О. П. Пунченко, В. М. Розина,
Н. Р. Сидорова, В. Д. Шадрикова, П. П. Щедровицкого, Н. В. Щиголевой та ін. У західній філософії можна виділити роботи Дж. Брунера, М. Вебера, Б. Л. Вульфсона, Г.-Г. Гадамера, Г. Г. Гофмана, Э. Дюркгейма, Г. Е. Зборовского, Г. Зиммеля, Ф. Г. Клумбса, Корнела Попы, Р. Р. Сингха, П. Сорокина, В. Франкла, М. Фуко, М. Шиллера та ін. Виклад основного матеріалу. Особливий статус соціальної комунікації проявляється в науці і освіті, де вона постає як цілеспрямований процес виробництва i передачі інформації. Інформація (з лат. «обізнаність, роз'яснення, виклад») «найчастіше розуміється як сукупність зібраних суб'єктом пізнання, якимось чином представлених, іноді вже й оброблених, систематизованих відомостей про явища і процеси навколишньої дійсності» $[9,48]$. Таке трактування інформації враховує специфіку комунікаційної взаємодії в освіті. Тут інформація розглядається як змістовна сторона зв'язку, яка веде від зовнішнього соціального світу до людини. У цій іпостасі вона $є$ і засіб і міра впорядкованості процесів, які складають зміст освіти, міру її організації, їй відповідає їх визначеність.

\section{Виклад основного матеріалу.}

У суспільних науках, а особливо в філософії та педагогіці, 3'явилися можливості розвитку нових форм навчання, заснованих на ідеях раціональності (тут раціональність розуміється як підвищення якості навчання за рахунок розширення передового досвіду), інформатизації, демократизації, гуманізації та гуманітаризації. Інфо-телекомунікаційні технології дозволяють конвергувати освітній процес як школу діалогу матеріальних і духовних культур, ставлять своєю центральною ідеєю формування фахівця високої культури. Впровадження інфо-телекомунікацій прискорює створення єдиного інформаційного простору, забезпечує доступ представників різних спеціальностей до інформаційних ресурсів цивілізації. Успіх у розвитку освіти пов'язаний із принципово новими принципами взаємодії в його інфрастурктурі, які розробляються на основі інфо-телекомунікаційних технологій і виступають в якості методологічної основи впровадження цих технологій в освіту $[4$, c. 75$]$. 
Раціональність висловлює змістовну і сутнісно-структурну характеристику освітнього процесу, фіксуючи одночасно не тільки факт його протікання, а й конкретний спосіб його існування. Раціоналізація знання по своїй природі $є$ інтенціональною, оскільки вона завжди $є$ зосередження суб'єкта над «чимось» за допомогою певної методології. Це творчий пошук істини. В освітньому процесі вирішення цієї проблеми висловлює комунікативний зв'язок його суб'єктів, але цей зв'язок є глибоким відображенням комунікативної раціональності.

На зміну старій парадигмі сьогодні приходить парадигма інтерсуб'єктивного розуміння i комунікації. "Сьогодні фокус дослідження перемістився, - зазначає Ю. Хабермас, - від когнітивно-інструментальної до комунікативної раціональності. Для нього парадигмічно не ставлення приватного суб'єкта до чого-небудь в об'єктивному світі, що можна уявити і з чим можна маніпулювати, а міжособистісні відносини, в які вступають здатні до спілкування і дії суб'єкти, якщо вони обертаються в середовищі природної мови, вживають культурно-віддані інтерпретації і одночасно звертаються до чого-небудь об'єктивного, загального для них соціального і відповідно до суб'єктивного світу» [10, с. 58]. Ю. Хабермас обгрунтовує сутність комунікативної раціональності, відзначає, що вона має свою структуру. Ю. Хабермас охарактеризував іï наступним чином: «Коли мовець висловлюється про що-небудь у рамках повсякденного контексту, він вступає у відношення не тільки до чогось наявного в об'єктивному світі, ... але ще і до чогось в соціальному світі .... і до чогось у своєму власному, суб'єктивному світі» [6, с. 198]. Комунікативна раціональність цілеспрямовано орієнтована на пошук істини через систему взаєморозуміння. Комунікація в освіті складає ядро суб'єктно-суб'єктних відносин, у яких реалізуються функції і методологія освіти, a також здійснюється головне завдання освіти - інформаційно-практична підготовка фахівця. Інформація, що має в цьому процесі особливе функціональне значення і самодостатню цінність, виступає, по суті, фундаментом процесу комунікації, за допомогою якого формується інтерсуб'єктивний світ особистості [11, с.66].

Світ освіти - це той світ, у якому живе суб'єкт навчання. У ньому він здобуває знання, які навчальний суб' єкт транслює після відбору і аналізу необхідної інформації по пізнаванню проблеми. Але світ суб'єкта навчання інтерсуб'єктивний остільки, оскільки він розкривається, як «світ культури, бо з самого початку повсякденність як процес навчання постає перед нами як смисловий універсум, сукупність значень, які ми повинні інтерпретувати для того, щоб знайти опору в цьому світі, прийти до угоди 3 ним » [12, с. 130]. Безсумнівно, унікальність освіти пов'язана 3 тим, що через нього ми не просто пізнаємо світ, а перетворюємо останній, щоб знайти опору в ньому, і скорелювати наші відносини з ним, які виявилися сьогодні вкрай необхідними для подолання ряду негативних глобальних проблем сучасності. Світ суб'єкта навчання інтерсуб'єктивний остільки, оскільки він розкривається як «світ культури», бо 3 самого початку повсякденність як процес навчання постає перед нами як смисловий універсум, сукупність значень, які ми повинні інтерпретувати для того, щоб знайти опору в цьому світі, прийти до угоди з ним [12, с. 130].

Як одна 3 підсистем ментальності виступає правосвідомість - модель світу з точки зору його правових аспектів. Правосвідомість, по суті, відображає ідентифікацію індивіда, з одного боку, 3 державою $з$ їі встановленнями, з обмеженнями, що накладаються суспільством, 3 іншого боку це та частина ментальності, яка встановлює норми добра і зла, справедливість, моральний борг, компроміс між собою та іншими. Ці дві сторони правосвідомості можуть виявитися такими, що конфліктують, якщо в ментальності закладено, що норми, які встановлюються державою, і справедливість не ідентичні. Це може викликати подвійне відношення до дійсності. У такій формі існує українська правосвідомість як частина української ментальності $[11$, с. 70]. Правосвідомість як частина народної свідомості, ментальності володіє в цілому іiі властивостями, є сконструйований людиною простір сенсів, що формується на основі образів дійсності. Ці образи, у свою чергу, відбираються, фільтруються заданими в конкретному суспільстві, нації системами координат нормами.

Вивчення соціальних взаємодій неможливо без урахування взаємовпливу об'єктивного (структурного) і суб'єктивного (інтенціального) світів. 3 позиції суб'єктивного підходу до світу теорія соціальної роботи спирається на феноменологічну методологію.

Феноменологічна орієнтація на розуміння світу, діалог і посередництво дає можливість аналізувати процеси як всередині відносно стабільних спільнот, так і всередині груп, що знаходяться в процесі розвитку, і формувати суб'єкт-суб'єктні відносини в соціальній сфері. 
Феноменологічний метод пізнання світу робить акцент на безмежних можливостях людей в «соціальному конструюванні реальності» (П. Бергер, Т. Лукман). Погляд феноменології спрямований на індивідуальне створення світу в нашій свідомості, на суб'єктивні аспекти людської поведінки. Пізнаючи предметний світ, людина конструює його в своїх думках, діях і комунікації. Зміна привласнюваних об'єктами смислів змінює внутрішній світ людини, iї дії і веде до суттєвих соціальних змін $[1$, c. 24]. Впорядковуючи в своїй свідомості смисли і значення е повсякденному житті, індивід формує образ «Я» як систему уявлень і відносин до себе, образ іншої людини і образ світу в цілому. В результаті у рамках життєвої практики реалізується особистісне самоздійснення і знаходиться соціальна впевненість. Правове регулювання охоплює всі сфери суспільного життя. Право як навчальний зміст задає умови для розвитку здібностей, істотним чином відмінних від здібностей, що формуються на науковому змісті, у тому числі на матеріалах інших курсів соціально-гуманітарного. Діюча в суспільстві людина є суб'єктом багатьох типів правових відносин цивільних, адміністративних, трудових, сімейних i т. под. Використання в навчанні відповідного правового матеріалу сприяє формуванню складного багатовимірного уявлення про себе, проходженню процесу ідентифікації. Необхідність діяти 3 урахуванням позиції інших людей, з урахуванням правових норм стає умовою для розвитку «Я» дитини як складноорганізованого щодо «Я» інших людей циклу - це розвиток уявлення про себе і Я-концепції [7, с. 48].

Людина, що діє в суспільстві, виявляється суб'єктом багатьох типів правових відносин цивільних, адміністративних, трудових, сімейних тощо. Використання в навчанні відповідного правового матеріалу сприяє формуванню складного багатовимірного уявлення про себе, протіканню процесу ідентифікації. Необхідність діяти з урахуванням позиції інших людей, з урахуванням правових норм стає умовою для розвитку «Я» людини, як складноорганізованого відносно «Я» інших людей. Якщо в новий час проблема ідентичності зводилася до того, щоб побудувати і потім охороняти та підтримувати власну цілісність, то в сучасному світі не менш важливо уникнути стійкої фіксації на якійсь одній ідентичності і зберегти свободу вибору і відкритість новому досвіду. Але якщо раніше психологічна ригідність (жорсткість) нерідко допомагала соціальному виживанню, то тепер вона частіше йому шкодить. Самоіден- тичність все більше сприймається сьогодні не як якась тверда, раз і назавжди сформована даність, а як незакінчений проект, що розвивається [3]. В умовах швидко змінного соціуму і зростаючої тривалості життя особа просто не може не самооновлюватись, і це не катастрофа, а закономірний соціальний процес, якому відповідає нова філософія часу і самого життя [6, с. 279].

Проблема визначення людиною свого місця в світі має безпосереднє відношення до питання про те, з якою реальністю вона себе ототожнює, в яку просторово-часову структуру вона поміщає своє існування. У зв'язку з проблемою ідентифікації суб' єктивного часу індивіда 3 часом «Іншого» необхідно зупинитися на багаторівності самого поняття «Інший». В якості останнього може виступати як суб’єктивна буттєва структура («Інший» як інше «Я»), так і об'єктивна буттєвість (соціальний простір-час якої-небудь держави, нації, певна історічна епоха, світ в цілому і світовий час, Бог і божественний час, або трансценденція тощо). В залежності від того, що вкладається в поняття «Інший», індивід може жити в одному часі з іншою людиною (або групою людей), зі своєю країною (у ритмі іiі соціального життя), відносити себе до певної історичної епохи, відчувати себе злитим зі світовим часом $[5$, с. 66$]$.

Дві людські істоти, що живуть в єдиному темпоральному потоці, повинні виявляти високий ступінь взаєморозуміння, внутрішнього споріднення, тобто між ними встановлюється, за висловом М. Бубера, «сутнісний зв'язок», в якому межі індивідуального буття виявляються прорваними. В стані «відвертості суті для суті» і виникає феномен особливого «простору-часу для двох». Ідентифікувати себе 3 чим-небудь означає злитися 3 вибраним об'єктом, інтегрувати його в себе або стати його частиною, а якщо це безліч об'єктів зі схожими властивостями, то стати одним із них. Таким чином, ідентифікацію можна розглядати i як різновид інтеграції, об’єднання. Останнє ж мовою людських відчуттів означає прийняття, любов $[2,97]$.

Правове регулювання охоплює всі сфери суспільного життя. Діюча в суспільстві людина $€$ суб'єктом багатьох типів правових відносин цивільних, адміністративних, трудових, сімейних i т. под. Використання в навчанні відповідного правового матеріалу сприяє формуванню складного багатовимірного уявлення про себе, проходженню процесу ідентифікації. Необхідність діяти з урахуванням позиції інших людей, з урахуванням правових норм стає умовою для розвитку «Я» дитини 
як складноорганізованого щодо «Я» інших людей. Право як учбовий зміст задає умови для розвитку здібностей, що істотним чином відрізняються від здібностей, що формуються на науковому змісті, зокрема на матеріалах інших курсів соціально-гуманітарного циклу. Це розвиток уявлення про себе і Я-концепції.

Для конструктивної побудови «Я-концепції» необхідно мати відповідну інформацію про загальні людські якості та особистісні характеристики. Такого роду інформацію учні здобувають через вивчення історії, літератури, курсів «Основи громадянознавства», «Психологія спілкування», «Основи філософії». Самопізнання дає змогу краще зрозуміти інших, а також це ключ до самостворення, самоосвіти, саморозвитку. Отже, набуваючи досвіду вирішення внутрішньо осо- бистісних протиріч, гармонізації свого внутрішнього світу, кожна особистість осмислює діапазон засобів вирішення своїх життєвих завдань, набуває навичок взаємодії з оточуючим світом i це відкриває доступ до потенційних особистісних ресурсів та допомагає динамічно змінювати стратегію поведінки в різних ситуаціях життєвого простору.

\section{Висновки.}

Як вирази комунікативно-раціональніх початків правова ідентичнисть неминуче фокусує рівень усіх змін особистості, що виявляються в елементах соціально-правової активності, у соціально-правових установках особистості, у відношенні до норм права, у готовності реалізовувати право, у реальній участі кожного індивіда в правових відносинах.

\section{БІБІЛІОГРАФІЧНІ ПОСИЛАННЯ}

1. Бергер П. Социальное конструирование реальности. Трактат по социологии знания / П. Бергер, Т. Лукман. - М.: «Медиум», 1995. - 322 с.

2. Бубер М. Проблема человека. К всемирному философскому конгрессу / М. Бубер // Специализированная информация по общеакадемической программе: «Человек, наука, общество: комплексные исследования». - М.: РАН ИНИОН, $1992 .-677$ с. 3. Гіденс Е. Соціологія / Е. Гіденс. - Київ: Основи, 1999. - 726 с.

4. Емелин В. А. Вавилонская сеть: эрозия истинности и дифференциация идентичности в пространстве Интернета / В. А. Емелин, А. Ш. Тхостов // Вопросы философии. - 2013. - № 1 - С. 74-78.

5. Карпенко В. Е. Техноинтеллектуализация культуры как философская проблема / В. Е. Карпенко // Розвиток основних напрямів соціогуманітарних наук: проблеми і перспективи. Збірник статей та тез доповідей за матеріалами III Всеукраїнської науково-практичної конференції з міжнародної участю. - Дніпродзержинськ: ДДТУ, 2016. - С. 65-67.

6. Карпенко Т. М. Людство як суб'єкт і як об'єкт NBICS-конвергенції / Т. М. Карпенко // Філософія науки: традиції та інновації. - 2013. - № 6. - С. 278-288

7. Лебедев С. А. Пересборка эпистемологического / С. А. Лебедев // Вопросы философии. - 2015. - № 6. - С. 53-64.

8. Мамардашвили Мераб Константинович. Классические и неклассические идеалы рациональности / Мераб Константинович Мамардашвили. - Тбилиси: Мецниереба, 1984. - 82 с.

9. Романов А. А. Массовые коммуникации / А. А. Романов, Г. В. Васильев - М.: Вузовский учебник, 2009. - 236 с.

10. Хабермас Ю. Моральное сознание и коммуникативное действие / Ю. Хабермас. - СПб.: Наука, 2000. - 377 с.

11. Чаплигін О. К. Трансгуманізм у сучасному людинознавстві: перспективи і виклики / О. К. Чаплигін, О. Є. Сук // Філософія у сучасному світі: Матеріали міського міжвузівського науково-практичного семінару, 21-22 листопада 2015 р. - Харків: «Точка», 2015. - С. 69-72.

12. Шюц А. Структура повседневного мышления / А. Шюц // Социологические исследования. - 1988. - № 2. - 129-137 с.

\section{REFERENCES}

1. Berger, P., \& Lukman, T. (1995). Sotcialnoe konstruirovanie realnosti. Traktat po sotciologii znaniia [Social construction of reality. A Treatise on the Sociology of Knowledge]. Moscow: «Medium» [in Russian].

2. Buber, M. (1992). Problema cheloveka. K vsemirnomu filosofskomu kongressu [The problem of man. To the World Philosophical Congress]. Spetcializirovannaia informatciia po obshcheakademicheskoi programme: "Chelovek, nauka, obshchestvo: kompleksnye issledovaniia». Moscow: RAN INION [in Russian].

3. Gidens, E. (1999). Sotciologiia [Sociology]. Kyiv: Osnovi [in Ukrainian].

4. Emelin, V.A. (2013). Vavilonskaia set: eroziia istinnosti i differentciatciia identichnosti v prostranstve Interneta [The Babylonian Network: the erosion of truth and the differentiation of identity in the Internet space]. Voprosy filosofii, 1, 74-78 [in Russian].

5. Karpenko, V.E. (2016). Tekhnointellektualizatciia kultury kak filosofskaia problema [Techno-intellectualization of culture as a philosophical problem]. Rozvitok osnovnikh napriamiv sotciogumanitarnikh nauk: problemi i perspektivi [Development of the main directions of socio-humanities: problems and perspectives]. Zbirnik statei ta tez dopovidei za materialami III Vseukrainskoi naukovo-praktichnoi konferentcii z mizhnarodnoju uchastju - Proceedings of The Third All-Ukrainian Scientific and Practical Conference. (pp. 65-67). Dniprodzerzhinsk: DDTU [in Russian].

6. Karpenko, T.M. (2013). Liudstvo yak subiekt i yak obiekt NBICS-konverhentsii [Humanity as a subject and as an object of the NBICS-convergence]. Filosofiia nauki: traditcii ta inovatcii, 6, 278-288 [in Ukrainian]. 
7. Lebedev, S.A. (2015). Peresborka epistemologicheskogo [Reassembly of the epistemological]. Voprosy filosofii, 6, 53-64 [in Russian]. 8. Mamardashvili, M. K. (1984). Klassicheskie I neklassicheskie idealu ratsionalnosti [Classical and non-classical ideals of rationality]. Tbilisi: Metsniereba [in Russian].

9. Romanov, A.A., \& Vasiljev, G.V. (2014). Massovue communikatsii [Mass Communications]. Moscow: Vuzovskij ychebnik [in Russian].

10. Khabermas, Yu. (2000). Moralnoe soznanie I communikativnoe dejstvie [Moral consciousness and communicative action]. Saint Petersburg: Nauka [in Russian].

11. Chapligin, O.K. (2015). Transgumanizm u suchasnomu liudinoznavstvi: perspektivi i vikliki [Transhumanism in modern human sciences: perspectives and challenges]. Filosofiia u suchasnomu sviti-Philosophy in the modern world: Proceedings of The Urban Interuniversity Scientific and Practical Seminar. (pp. 69-72). Kharkiv: «Tochka» [in Ukrainian].

12. Shyuts, A. (1988). Struktura povsednevnogo mushleniya [Structure of everyday thinking]. Sociologicheskie issledovaniya, 2, 129-137 [in Russian].

\section{Кравцов Юрій Сергійович}

Доктор філософських наук, професор

Дніпровський державний технічний університет

51900, Кам’янське, Дніпропетровська область, Дніпробудівська вулиця, 2

\section{Kravtsov Yuriy}

Full Prof. Dr.

Dniprovsky State Technical University

2, Dniprobudivskaya St., Kamyans'ke, Dnipropetrovsk region, 51900, Ukraine

Email: kravtsovyuri6@gmail.com

Цитування: Кравцов Ю. С. Комунікативна раціональність як феноменологічна складова правової ідентифікації / Ю. С. Кравцов // Науково-теоретичний альманах «Грані». - 2018. - Т. 21. - № 5. - С. 109-114.

Citation: Kravtsov, Y.S. (2018). Komunikatyvna ratsionalnist yak fenomenolohichna skladova pravovoi identyfikatsii [Communicative rationality as a phenomenological component of legal identification]. Scientific and theoretical almanac «Grani», 21(5), 109-114. 